\title{
Financial Revolution in Republican China during 1900-1937: a Survey and a New Interpretation
}

\author{
Debin Ma \\ Economic History Department \\ London School of Economics \\ Email: d.ma1@1se.ac.uk
}

Jan. 2019

\begin{abstract}
This paper surveys the phenomenal transformation of banking and finance, public debt and monetary regimes during 1900-1937, a period of great political instability in Chinese history. To understand why growth in these strategic sectors occurred, I highlight the role of the institutional nexus of Western treaty ports (with Shanghai being the most important) and China Maritime Customs service, a relatively autonomous tax bureaucracy. My new interpretation on the importance of this mechanism sheds new light on the role of Chinese political institutions, the impact of the West and the ongoing Great Divergence debate.
\end{abstract}

Keywords: China; financial revolution; public debt; credible commitment.

JEL code: N15; N25; N45; E42.

Acknowledgement: I want to thank the comments and discussion with Loren Brandt, Changwei Ma Tom Rawski, Yi Xu, Hans van de ven and Hongzhong Yan. I alone remain responsible for the errors. 


\section{Financial Revolution in Republican China during 1900-1937: a Survey and a New Interpretation}

The period of 1900-1937 straddles several sub-periods of a tumultuous era in modern Chinese history. It starts disastrously with Qing's calamitous military defeat by Western (and Japanese) allied forces over the suppression of the Boxer Rebellion in 1901. In the wake of this defeat, Qing embarked on a bold modernization reform in 1905, modelled after Japan's Meiji Restoration, but only to collapse in 1911. China's subsequent Republican era (1911-1949) begins with the Beiyang decades of 1911-27 - also better known now as the Warlord era ruled by the so-called Northern regime in Beijing. The subsequent Nanjing era was marked by founding of the new Nationalist government based in the capital city of Nanjing in 1928 until the full scale Japanese invasion in 1937.

This paper offers a survey and reassessment on the unusual transformation in banking and finance, public debt and monetary regimes amidst political turmoil of the period. In particular, I aim to explain the puzzle why sectors such as modern banking, which are often most vulnerable to the security of property rights and contract enforcement, have become the vanguard of growth during this era of pervasive uncertainty. This is particularly enigmatic in view of China's relative under-development of formal banking institutions and financial markets particularly for public debt even during her more dynamic or stable periods. ${ }^{1}$ One issue with China's financial underdevelopment may well have been linked with the absolutist nature of China's traditional regime, which poses the so-called credible commitment problem in the political science literature: a government strong enough to define and protect property

rights is also strong enough to abrogate them for its own benefit. ${ }^{2}$ But interestingly, a landmark constitutional reform during 1903-1911 which aimed at constraining the power of an absolutist imperial regime may have inadvertently led to a partial political collapse and paralysis in China. So, throughout the first decades of the $20^{\text {th }}$ century, the Republican China was engulfed by the reverse of the credible commitment problem: the government often became too weak to provide normal social order or implement real institutional reform. Hence, the rise of modern banking and financial market especially for governmental debt during this era remains a fascinating puzzle.

\footnotetext{
${ }^{1}$ See Brandt-Ma-Rawski (2011) for a survey on the Great Divergence debate on when and why China was falling behind Western Europe in the early modern era.

${ }^{2}$ See North and Weingast (1989) for the well-known case of Glorious Revolution in 1688 where a constitutional arrangement that placed parliamentary checks on the executive power of the English Crown and in turned provided credible commitment.
} 
I argue that it was precisely the temporal retreat of a centralized imperial power in China that allowed the rise of a quasi-political structure dominated by Western and Chinese business elites. This structure rested on the institutional nexus of Western treaty ports (with Shanghai being the largest and most notable) and Maritime Customs service - perhaps China's first modern and independent civil and tax bureaucracy. The key feature was a financial-fiscal mechanism that offered a substitute form of commitment for the security of property rights and the repayment of government bonds. Both these institutions were all intimately connected with Western institutions and hence the accidental products of Western imperialism in China. They initially only served to protect the limited Western or foreign business interests in the context of imperial extra-territorial privileges during the second half of the $19^{\text {th }}$ century. However, in the wake of 1903 constitutional reform, this mechanism began to be transferred to the Chinese context and to impinge on China's domestic affairs following Qing's collapse in 1911. More specifically, the relative political autonomy of treaty ports and Maritime Customs began to inadvertently act as effective system of checks and balances that constrained (as well as undermined) China's political control at the centre and triggered the equivalent of a financial revolution marked by a viable free-banking system, the rise of credible private convertible bank notes and public debt under a silver standard increasingly unified under a regime of national coinage through an era of national disintegration.

The emergence of this quasi-structure in China during this unique era became an anomaly in Chinese history. Long characterized by a centralized and absolutist political rule with undisputed property rights over people and properties, China's absolutist rulers often respected property rights and contract enforcement enforce contracts only in the condition of stable long term rule in the so-called stationary banditry equilibrium. ${ }^{3}$ But what is absent in this traditional Chinese equilibrium is the kind of financial innovation associated with the rise of autonomous cities and merchant elites as often observed in the Western European context (see David Stasavage's recent survey 2016). Hence, what happened in China's early $20^{\text {th }}$ century financial revolution was precisely a transfer of the European type of city-state driven financial revolution onto the Chinese context. In this regard, my survey on this short but unusual episode in Chinese history offers insights on some of the most important and controversial issues related to Chinese and global economic history, the question of political centralization versus fragmentation, the impact of the West in China, as well as the ongoing Great Divergence debate.

I divide my survey into four sections followed by a conclusion. The first section provides a brief survey of historical background and economic record for this era. The second

\footnotetext{
${ }^{3}$ See Ma (2012), Ma and Rubin (2017) for an exposition on the historical evolution of traditional Chinese political regime in the stationary banditry framework.
} 
section narrates the rise of the Shanghai International Settlement and Chinese banking community. The third section focuses on Chinese Maritime Customs, public debt and monetary transformation in this period. The fourth section illustrates the full swing of a financial revolution in the Nanjing decade and its end.

\section{China in 1900-1936: History and Economic Performance}

The onset of Western imperialism in mid- $19^{\text {th }}$ century represented a watershed in Chinese history, challenging the economic, political, institutional, and ideological underpinnings of the Qing empire. Western imperialism never subjugated China to full colonization but manifested itself as a series of trading rights, leased territories, treaty ports with extraterritoriality (for foreign business and residents) or spheres of interest in China in the 19$20^{\text {th }}$ centuries. The late-Qing governmental response in the second half of the $19^{\text {th }}$ century was limited to mostly the modernization of Chinese military through a series of government financed or controlled Western style, capital-intensive industrial enterprises under the banner of Self-strengthening movement (1860-1894). Meanwhile, little was done to support the private sector or promote key modern public infrastructures such as modern railroads in the $19^{\text {th }}$ century (Brandt, Ma and Rawski, 2011).

The 1894-96 naval confrontation between China and Japan became a turning point. China's defeat by a nation long regarded as her one-time student brought a profound mental shock that spelled the end of the Self-strengthening movement and opened the path towards a constitutional reform during 1903-11 modeled directly after Japan's more comprehensive Meiji reform. The constitutional reform recognized the centrality of the private sector to a market economy and paved the way for the introduction of modern public infrastructure. But reform was as short-lived as the final years of the empire, which collapsed in 1911. What ensured in the following two decades defy simple classification as there have been at least two political regimes and three different eras: the Northern or Beiyang regime (1911-1925), the period of Northern expedition (1925-27) and the Nanjing regime (1927-37). The Northern regime, at least until 1923, experimented with China's first ever parliamentary democracy and flirted with the idea of Federalism, something fundamentally antithetical to traditional Chinese political tradition of centralization. ${ }^{4}$ In that sense, China, as eloquently argued by Frank Dikotter (2010), had never seen an era as open as her Beiyang era, not just in borders and trade, but also in governance and minds. Despite the weakened or even at times dysfunctional political rule, China's so-called Warlord era made great strides in legal reform, upheld the ideal of constitutionalism and achieved admirable diplomatic success in the international arena. There was also greater scope for political experimentation, the

\footnotetext{
${ }^{4}$ See Ma 2012 for a framework on the traditional political system in China.
} 
strengthening of local governance, flourishing of civil societies, free and independent academic and intellectual institutions. It had China's first ever - if not the last - genuine experiment with Parliamentary Constitutionalism, a recurring political theme both championed and reprimanded today in China.

But parliamentary politics Chinese style also saw the constant shuffle of governmental cabinets, scandalous vote-rigging and corruption (Nathan 1976, Waldron 1995). With political disintegration, Warlords of different persuasions or fractions brought different degrees of terror and exploitation, through fiscal extraction, the printing of worthless currencies, kidnapping of rich merchants or prey on the hapless peasantry. Arthur Waldron (1995) noted a progressive scaling-up of military warfare that were spilling over to China's most productive regions or even treaty ports under foreign jurisdiction by the 1920s. Even those who pointed out the limited extent of warfare damage and existence of enlightened and stable warlords who promoted economic reforms in their territories would have to agree that political unrest and civil wars made any long-range investment extremely precarious (Rawski 1989, Sheridan 1983 and Ma 2008).

In spite of these contradictory developments, something close a growth "miracle" emerged. The initial impetus may have come from the signing of the treaty of Shimonoseki in 1896 after China's naval defeat by Japan. The treaty granted foreigners the right to establish factories in the treaty port which opened the floodgate of foreign direct investment in China and indirectly legitimized Chinese modern enterprises. Along with the onset of WWI which led to a temporary withdrawal of Western industrial competition, they set off the first major wave of Chinese industrialization. Activity in mining and manufacturing accelerated sharply from its small initial base from the end of the $19^{\text {th }}$ century, making average nominal annual industrial investment by Chinese nationals in 1914-1925 11 times that of the 18401911 Overall industrial output growth showed double-digit real annual growth during 19121936 (Ma 2008). Despite the importance of foreign investment in Shanghai and especially in Manchuria, Chinese-owned companies produced 73 percent of China's 1933 factory output (Brandt et al 2014). External trade also boomed with nominal value more than doubled between 1910-1928 (Mitchener and Yan 2014). Industrialization led to import substitution and rising product diversity in both internal and external trades (Wolfgang, Li and Shiue 2012). Meanwhile, public infrastructure improved with China's railway network growing from a paltry 364 kilometers in 1894 to over 21,000 by 1937 (Brandt et al 2014).

All in all, this era may well be China's best - for its unprecedented openness, the origin of modernity and liberalism, and the beginning of modern economic growth - and her worst - for its economic dislocation and a profound sense of national weakness and 
humiliation. While the economic growth aspect of this era has been extensively explored elsewhere, here we turn now to the financial transformation. ${ }^{5}$

\section{Treaty Ports and Chinese Banking: the case of Shanghai International Settlement}

The most visible and enduring presence of Western imperialism in China is a series of treaty ports opened to free trade under the so-called "unequal treaties" which granted Western residents and business there extraterritorial rights to be governed by their own law rather than Chinese law. While a total of possibly more than 40 cities opened in four successive waves between the 1840 s to the $1910 \mathrm{~s}$, the size, importance and the internal governance structure of these ports varied significantly ranging from giant metropolis such as Shanghai to towns that existed only in name (Fei 1991, Jia 2014). For better or worse, it was under the extraterritoriality that China's treaty ports emerged as the financial centers of the era, first for foreign banks during the later $19^{\text {th }}$ century then by Chinese banks after the $20^{\text {th }}$ century. Most notable among them are Shanghai, Tianjin and Wuhan, all serving their respective macroeconomic regions in China (Ma and Zhao 2017). Among them Shanghai's position is dominant, which alone claimed nearly half of China's financial capital and housed half of the banking headquarters during the 1920s and 1930s (Ma 2008, Bank of China Economic Research Institute 1935, pp. 508-517). My current survey focuses on Shanghai whose dominant position held the key to unraveling China's financial revolution.

Shanghai was one of the five designated treaty ports opened up by the treaty of Nanjing signed after the First Opium War of 1842. It grew from a modest market town into a major city under separate jurisdictions of British, French and American Concessions as well as Chinese quarters. In 1863, the British concession merged with the American quarters to form the International Settlement for all Western (and later Japanese) residents while the French Concession remained separate throughout. From its very early days, the Western merchant elites of the Settlement had desired and fought for self-rule against direct administrative rule from the far-flung Imperial capital of London. The governance structure of the Settlement followed that of a Medieval European type of incorporated urban communities where merchant elites practiced self-rule often with charters granted by larger territorial rulers. This is an institutional feature that distinguished from most other treaty ports in China or even the

\footnotetext{
${ }^{5}$ See Rawski 1989, Ma 2008, Brandt et al 2012. Question remains on how much of these impressive achievements in the modern sectors and in major coastal urban centers translate into nationwide improvements. Given the dominant share of agriculture in GDP, national growth rates are less sanguine: even the most optimistic re-assessment of per capita GDP estimates only yielded real annual per capita GDP growth rate no higher than 2\% between 1911 and 1936, a respectable but not spectacular rate by the standards of the time. See Rawski 1989, Ma 2008 and See Richardson 1999.
} 
neighboring French Concession, which had been under the administrative rule of the French consular appointed from Paris. This model of self-government with limited representation by tax-paying multi-national - not just British - business elites has led Isabella Jackson to define Shanghai International Settlement as a case of transnational colonialism. ${ }^{6}$

The Settlement organized a Municipal Council whose members were elected by the ratepayers association that consisted of tax-paying Westerners in the Settlement. It operated with its own mini-Constitution: the Shanghai Land Regulations signed with the local Chinese authority in 1854 and subsequently revised in 1866. It Judicial powers over foreign residents were, under the grant of extraterritoriality, vested in the Consular Courts of the foreigners concerned, or, in the case of unrepresented foreigners or Chinese, in the International Mixed Court. The Municipal Council had a right to sue in these courts, and could in turn be sued in a court elected from the Consuls of the Treaty Powers, known as the Court of Consuls. As a general rule, the Council could make no arrests except on a warrant of the proper court. This institutional structure placed the Settlement on a foundation of limited power and rule of law. The Municipal Council levied land and property taxes and business license fees, ran its own prison and police squad with the additional support of a volunteer army in times of need. In comparison with the Chinese quarter governed by the local Qing government, businessdominated Council was far more efficient in the provision of public goods (or semi-public goods) ranging from the maintenance and improvement of city roads, transportation and communication infrastructures, public utilities and port facilities. ${ }^{7}$

The critical phases of growth in the Shanghai International Settlement are intricately linked with major political turmoil within China. The first phase occurred in 1853 when the attack and occupation of the Chinese territory in Shanghai by the so-called Small Sword Society - a branch of the devastating Taiping Rebels - pushed massive number of Chinese refuges into the shelter of the International Settlement and French concession protected by their extraterritoriality. The influx of Chinese residents was followed by Chinese business, wealth and entrepreneurship set off a boom to the Shanghai real estate. The outcome is that Chinese formed the overwhelming majority of residents in the Settlement and paid bulk of the taxes but without any formal representation on the Municipal Council until 1928 (Ma 2011, Jackson 2018).

The second critical phase of the Settlement came in 1911 when Qing collapsed. Taking advantage of China's political weakness, both the International Settlement and the French Concession made their greatest territorial expansion to reach 33 square kilometers, 1.5 times the total size of foreign concessions in the other treaty ports in China. When the Qing

\footnotetext{
${ }^{6}$ See Jackson (2018) and Ma (2011). The only model of multi-national settlement is Gulangyu in Xiamen, Fujian province, which was an isolated island.

${ }^{7}$ See Ma 2011, Jackson 2018, Fan 2012, Yang 2014 on the inner working of the Municipal Council.
} 
magistrate in Shanghai absconded during the 1911 revolution, the International Settlement took over the Mixed Court and began to appoint its own Chinese legal personnel. ${ }^{8}$ By then, the Settlement became a de-facto city-state with full territorial jurisdiction over all its residents, Western or Chinese (Ma 2011). This marks a turning point where an institution previously intended for foreigners began to insert itself as an independent political force in China's national polity. Beyond security and order, the institutional model of the International Settlement has exerted a profound and lasting impact on political organization, legal regime of property rights and contract enforcement, fiscal structure and civil societies.

Shanghai's treaty port status had long attracted what was to become some of the world's premier Western banking institutions such as HSBC and Chartered Banks (Horesh 2009). But modern Chinese banks only began during the dying years of the empire when Qing recognized their glaring absence and critical importance. The first state-sponsored bank, the Imperial Bank of China, established in 1897, was modelled after HSBC. The Imperial Bank later morphed into the Bank of China and along with the Bank of Communication, were to form the two most important governmental banks. By 1911, China also saw the establishment of 17 other private commercial banks (Cheng 2003, chapter one).

China's modern banks were soon to meet their first major test of governmental tyranny. In 1916, confronted with a major fiscal crisis, the nascent Republican government in Beijing, resorted to the printing press for fiscal revenue and ordered the government banks, namely Bank of China and Bank of Communications to suspend paper note conversion to silver, a move that was to bring panic to China's nascent financial sectors. Given these were governmental banks, bank managers who dared to resist the governmental order could be dismissed or replaced. To avert a potential financial crisis, the Bank of China Shanghai Branch managers, after consulting with the Judges of the Mixed Court, instructed several shareholders and depositors to file a symbolic law suit against the bank. The suit itself would bar the Chinese government from removing the managers who were pending a verdict by the Mixed Court, which was under the jurisdiction of the International Settlement (Cheng 2003, p. 57). The outcome is that the Shanghai branch of Bank of China along with other Western banks in the International Settlement maintained full silver convertibility throughout the note suspension period while other governmental banks had to accede to the order and suffer the devastating bank-runs. 1916 marked a turning point when Shanghai - eclipsing Beijing - was to emerge as China's most important financial center. Subsequently, the Shanghai bankers were to play a leadership role in the privatization of these two government state banks by

\footnotetext{
${ }^{8}$ The work by Thomas Stephens on the Mixed Court in 1911-1925 led him to emphatically state that "throughout all the political vicissitudes of the Yuan Shikai era..., throughout all the marching and countermarching of the armies of the warlords and their murdering marauding hordes, ... Shanghai remained an oasis of peace, order and good government in a China torn into convulsions by revolution, banditry and civil war, Stephens 1992, pp. 104-6.
} 
revising the bank bylaws, enhancing the influence of private shareholders over governmental control (Cheng 2003, p. 59-62, Du 2002). The locus of China's modern banking were increasingly concentrated in the foreign concession areas of large treaty ports with increasing autonomy and independence from political interference during the entire Warlord era.

Prior to the arrival of modern banks, China had a thriving indigenous banking community, characterized by a multitude of small scale and often family owned operated native banks with unlimited liability, known as Qianzhuang (钱庄) in Shanghai and the Lower Yangzi area. The Native Bankers have long operated as money exchangers and have been the regulator of the traditional monetary standards in the domestic market, which was a bewildering mixture of silver bullion, foreign silver coins (imported mostly from South America), government minted Chinese copper cash along with some private notes. Native banks are the major financial intermediaries of domestic long-distance in agricultural goods throughout China and use their vast network to transfer bills, notes and silver dollars across major trading centers. They regulated Shanghai tael, an abstract unit of silver ingot defined by weight, purity and fineness and publicized daily exchange rates of tael versus silver dollars, which reflected short term market demand for silver dollar as a medium of exchange anchored on the intrinsic value of the silver tael. $^{9}$

The Shanghai native banks had organized themselves into guilds possibly as early as the $18^{\text {th }}$ century. But the major expansion and transformation of what is then Shanghai Native Bankers' Association came when it moved from the Chinese part of the city to the new location within the Settlement in 1917. The Association played a crucial role in the promotion and diffusion of a Chinese version of silver dollar, minted first by the Beijing government in 1914. In 1916, the Association made a major move to use domestically minted coins - mainly the so-called Yuan Shikai silver dollars - for their daily tael/dollar exchange rate quotations rather than foreign silver dollars. Chinese silver dollars began to spread rapidly as, according to a survey in 1924, out of 960 million silver dollars in circulation, 750 million were Yuan Shikai dollars and only 30 million were foreign silver dollars (Kuroda 2005, p.114). Overtime, the dominance of the Yuan Shikai silver dollar over time paved the way for the rise of a single silver dollar standard (delinked from the silver tael) (Ma 2013). As the decades proceeded, silver dollars were gradually replacing silver taels as a medium of exchange even in rural areas. These developments culminated in the official establishment of a single silver dollar standard promulgated in 1933 under the new Nationalist government in Nanjing, a major achievement only made possible after two decades of monetary transformation

\footnotetext{
${ }^{9}$ The safeguard was institutionalized with the establishment of relatively independent silver assaying bureaus (公估局) across major commercial cities in China, with Shanghai again leading the way. These bureaus or offices, established from the late $19^{\text {th }}$ century, supported by local commercial guilds, banking communities, or local and regional governments, were instrumental in setting up and upholding the local standard of silver tael (Ma 2013).
} 
occurred, ironically, through periods of national disintegration. ${ }^{10}$

In 1918, the powerful modern Chinese banks formed their own Shanghai Bankers' Association. Together with the Native Bankers' Association, they coordinated collective action, lobbied the Municipal Council, Chinese government and other formal public institutions and disseminated economic information and financial statistics through the publication of professional journals and newspapers. ${ }^{11}$ By taking advantage of the freedom of association and rule of law there, both the native and modern Chinese bankers turned geographic space of the Settlement into a critical staging ground to reproduce the model of Western style mercantile city-state on China's "extra-territory" in spite of their complete absence of representation on the Municipal Council.

Overall, the 1910s and 20s would mark the heyday of International Settlement and Shanghai in general, with her population doubling from only half a million in the $1890 \mathrm{~s}$, to over a million in the 1910s, and to about 3.5 million in the 1930s. By the 1930s, Shanghai alone produced $41 \%$ of national manufacturing output (48\% if excluding Manchuria), absorbed $46.4 \%$ of total FDI in China and $67 \%$ of FDI in manufacturing, more than half of China's foreign trade. Shanghai was the commercial, financial and industrial city of China in the early $20^{\text {th }}$ century (Ma 2008).

\section{China Maritime Customs and Public Debt}

The second key institution - China Maritime Customs - had similar origin and trajectory to that of the Shanghai International Settlement and treaty ports. The low fixed tariffs imposed by the unequal treaties on China by Western powers were initially collected by Chinese customs officials. But when Taiping Rebellion disrupted the function of Chinese customs agencies, foreign consuls set up the China Maritime Customs in Shanghai in 1854 to oversee the collection of maritime trade taxes that would have otherwise gone unpaid. Although an Imperial Chinese organization in name, the Customs became largely autonomous from the Chinese government with Britons dominating the foreign staff of the Customs, followed by large numbers of German, U.S., French, and later Japanese staff amongst others. Promotion of Chinese nationals into senior positions only started in 1929. (Hans van de ven 2014).

Its responsibilities soon grew to include domestic customs administration, postal administration, harbor and waterway management, weather reporting, and anti-smuggling operations. The Service published monthly Returns of Trade, a regular series of Aids to Navigation and reports on weather and medical matters. It also represented China at over

\footnotetext{
${ }^{10}$ New research reveal rapid improvement in monetary integration as measured by the convergence of dollars versus tael exchange rate across major urban centers from the early 1910s. See Ma and Zhao 2018.

${ }^{11}$ See Du 2006 for a detailed and insightful study of Shanghai Native Bankers’ Association.
} 
twenty world fairs and exhibition, ran some educational establishments, and conducted some diplomatic activities. With over 20,000 people in forty main Customs Houses across China and many more subsidiary stations, it was rapidly evolving to become China's first centralized hierarchic bureaucracy when China herself was descending into political disintegration. ${ }^{12}$ The autonomy, efficiency and probity of the Chinese Maritime Customs was to have long-lasting influence on the Chinese economy. Even under the Nanjing regime, the Customs maintained a certain degree of autonomy, in fact, in many cases, provided an administrative model of efficiency, transparency and political neutrality for the Nanjing government's own Ministry of Finance (Strauss 1998, chapter 3).

Like the International Settlement, the second critical phase for Maritime Customs came in 1911 when Qing collapsed. Prior to 1911, the Customs exercised no direct control over the tariff revenue collected but rather to only conduct accurate assessment and accounting of the Customs dues and duties collected at various treaty ports. The actual collecting, banking, and remitting of the Customs revenue had been arranged at each port by the Chinese superintendant (Wright, p. 1). With the collapse of Qing and the impending threat to the security of revenue often pledged as security for governmental debt, the Maritime Customs effectively took over the collection of the Customs revenue and the remittance of the net revenue through negotiation with imperial powers. Overtime, Maritime customs revenue were to form possibly the most secure and important form of central revenue for a weakened Beijing government when her traditional sources of tax revenue such as land tax were often retained by the increasingly autonomous local warlord governments. Maritime Customs revenue tracked the increase in China's foreign trade, nearly doubled from about 40 million Haikuan taels in 1912 to about 80 million in $1927 .{ }^{13}$ The revenue reached a share in the range of 20 to $50 \%$ for the Beijing government (van de ven 2014, Yan 2012, p.220). But more importantly, the control of Maritime Customs over the revenue became critical for the subsequent transformation of Chinese public finance.

In traditional China, the nature of an absolutist political regime with unquestioned rights over all properties and people posed a fundamental dilemma to any form of formalized public debt. Indeed, in an ideology "everything under the heaven belongs to emperor", governmental "borrowing" or "repayment" is even conceptually difficult let alone credible (Chen 2003, 106). In Chinese dynastic histories, the piling up of debt by a dynasty was regarded as symbol of bad rule and the portent of a dynasty's end (Van de ven, 2014, p. 136). De-facto "borrowing" did happen but often in the form of extortion, forced contribution, selling of

\footnotetext{
${ }^{12}$ Its outposts had ironically served China's only visible administration in far outlying regions such as Tibet and Xinjiang, where the Nationalist government had yet to exert any form of actual political control, see van de Ven 2014.

${ }^{13}$ For Maritime Customs revenue data, see graph 5.1, chapter 5, van de Ven 2014, For Chinese foreign trade data, see figure one in Mitchener and Yan (2014)
} 
offices and status to a small circle of bureaucrats and merchant elites (Ma 2014). Even during the second half of the $19^{\text {th }}$ century domestic public borrowing used for quelling rebellion and paying off foreign war indemnity often quickly deteriorated into forced contributions and extraction on Chinese wealthy elites (van de ven 2014, chapter 4).

Initially, when Chinese government borrowed from the foreign market, its obligation to repay was relatively credible partly due to the coercive power of Western gunboats and through the important intermediary institution of China Maritime Customs, the agency relatively insulted from the threat of the Chinese imperial government. ${ }^{14}$ When in 1911, the Maritime Customs directly took over the collection and remittance of the Customs revenue, it opened an account with HSBC which eventually became the custodian bank of that portion of Customs revenue pledged as security for the service of the government's foreign debt. ${ }^{15}$ It was this arrangement, as argued by Stanley Wright, that "China, since the outbreak of the (1911) Revolution, not only kept faith with thousands of her foreign bondholders throughout the world, but also to some extent held in check the disruptive forces set loose by the Revolution" (p. 9).

This institutional mechanism for the external market was soon to be transferred to become the cornerstone for a domestic market for Chinese governmental bonds handled through large Chinese public banks who have, as we see earlier, won independence from the 1910s onwards. In 1914, the Beijing government set up a relatively independent National Loan Bureau (内国公债局) whose board members were composed of Chinese and Western Bankers and Maritime Customs officials. It adopted a full Western practise ranging from accounting to repayment procedures; or as is literally put, it is "draped in a Western dress" (Okamoto 1999, p. 381-2). The key role was for the Bureau to ensure that tax revenue earmarked for debt repayment be directly remitted to special revenue account set up in the Western banks and later to Chinese banks headquartered in the International Settlement of Shanghai. The mechanism partially yield to Frances Algen, the new Maritime Customs Inspector General, effective veto power over government's borrowing. Algen was largely distrustful of the Beijing government given her history of raiding Chinese banks driven by fiscal needs as seen in the 1916 note suspension crisis. From the 1920s, through combined efforts of Bankers' association in both Shanghai and Beijing, Chinese Banks such as Bank of China and Bank of Communications began to play increasingly important role in the operation of public debt anchored on the National Loan Bureau, where all relevant tax revenue (including Maritime Customs) earmarked for the servicing of public debt were placed

\footnotetext{
${ }^{14}$ For the rise of a foreign market for Chinese public debt, see Van de ven, chapter 4.

${ }^{15}$ Initially, two other banks, Russo-Asiatische Bank and Deutsch-Asiatische Bank also served as the Custodian banks. They relinquished their roles following German defeat in WWI and subsequent rise of Soviet Union. Wright, p. 9. For details of this institutional arrangement and banking consortium before WWI, also see Okamoto, pp.376-380 and Van de ven, chapter 4.
} 
in the custodianship of the Maritime Customs. Indeed, between 1912 and 1926, a total of 60\% of domestic public debt were securitized on the revenue of Maritime Customs and those Native Customs that were partially under the control of Maritime Customs (Liu 2008, p.239). This led to the rise of an unusual alliance between the Bankers - Chinese or Western - and the China Maritime Customs (Yan 2015, Okamato 1999, chapter 7 Van de ven chapter 5).

The successful floatation of government bonds spawned an active primary and secondary market. Although stock exchanges were established in Beijing and Shanghai from 1918 and 1920 respectively, the bulk of the trading of Shanghai Stock Exchange was in governmental bonds which occupied a staggering share of $98 \%$ with only $2 \%$ in corporate shares and bonds (Yan 2015, p. 116; Coble, p 75-76). An important consequence of banks' increased holding of securitized governmental bonds -long misunderstood or neglected - is the rapid increase in the bank's capacity to increase its issue of bank notes and augment lending capacity. China's banking regulations allowed modern banks to use securities - which were composed of mostly governmental bonds - in the range of $40 \%$ to serve as reserves for bank notes (Brandt and Sargent 1989, p.40). Hence, the credibility of governmental bonds and the functioning of the Sinking Fund became a critical barometer for the reputation of banknotes issued by both public and private banks and to certain degree the entire banking sector. Indeed, the bond market itself often tracked the vicissitudes of the shifting bargaining power between the government and bankers over the control of fiscal revenue and sink fund. ${ }^{16}$

Figure 1 plots prices for one of the most reputable government bond issued in 1914 (also called Republican $3^{\text {rd }}$ year bond) issued with good security and was paid off completely by 1925. Price trend as captured figure 1 reveals vividly the rise and fall of public's confidence in Beiyang government's fiscal position. The infamous banknote suspension incident in 1916 marks the first sharp dip in the bond price. It was not until 1918 that confidence slowly restored to the market partly as new government debts were issued to recuperate those overissued banknotes from the 1916 banknote suspension fiasco. However, these new debts soon began to accumulate, again eroding public's confidence in the government's ability to repay. Pressured by large Chinese banks with substantial holdings in government bonds, the Beijing government began what was later known as the first bond consolidation by, among other things, shoring up the sink fund and putting more of the earmarked tax revenue under effective control of Frances Algen, the Inspector General of the Maritime Customs (Ma and Yao 2014, Liu 2008, 132-142). ${ }^{17}$ Bond prices began to improve from the end of 1921 until 1925.

Insert Figure 1 here

\footnotetext{
${ }^{16}$ See Coble Jr. 1980, pp. 90-108, Jiang 2003, Wright, 1935. In particular, see Ma and Yao 2014 on the details of three major debt restructuring in 1921, 1932 and 1936.

${ }^{17}$ For bond price series in 1921-1942, see Ho and Li 2014, p.420, Figure 1.
} 


\section{The Nanjing Era and Financial Revolution: the Beginning of an End}

Initially, the Nationalist government, even before 1927 when she established her capital in Nanjing, regularly resorted to forced loans or extortions on wealthy banking and industrial elites for its fiscal needs (see Parks Coble Jr. 1980, p. 35-36 and p. 43-46). From 1928 onward, the new finance minister, Song, Ziwen, began a policy of cooperation with Shanghai bankers and took over some of the good practices initiated in the Beiyang decade to create a genuine market for government bonds and securities. Indeed, Zhang Jia'ao, the Shanghai Banker who had orchestrated the privatization of the main governmental Banks in Shanghai following the 1916 Bank note suspension incident, was said to have admonished Mr. Song that the Nationalist government is better off "establishing the reputation of governmental debt than constantly pressuring the bankers for monetary advance" (Jiang 2003, pp.236-7). To convince investors of the safety of governmental bonds, the Nanjing government issued each bond secured on income from a tax source, the most important of which is the Customs revenue. Payments to the bondholders were handled by the Sinking Fund Commission (国库 基金保管委员会), which was headed by a private banker and with nine representatives from the Shanghai banking community and five from the government (Coble Jr., 1980, p. 72-3). Each month, the Inspector General of Maritime Customs transferred funds directly to the board of trustees to cover payments secured on the customs revenue while payments secured on other tax revenue were held by the Shanghai Bankers' Association (Coble Jr, 1980, p. 7078, Wright 1935, chapter one).

Under this institutional arrangement, Shanghai banks became the largest holder of government bonds, holding somewhere between one half to two thirds of Nanjing government bonds at the end of 1931 (Coble JR, p. 74). In fact, governmental bonds became the main portfolio among Chinese banks in Shanghai in general, far outweighing the share going to finance private enterprise (Yan 2015). Overall, the amount of domestic debts issued in 19271931 was nearly the double the amount issued during the entire Beiyang era of 1912-1926. While during the Beiyang era, the share of domestic to foreign public debt was 1 to 7 , it became 6 to 4 in the Nanjing decade of 1927-36. ${ }^{18}$ This marked perhaps the first time in Chinese history that the Chinese government could tap into the wealth of Chinese elites or even average people for borrowing without the usual coercion and predation.

The importance and success of governmental bonds in the early Nanjing era are confirmed by some theoretical and empirical works. Based on a theoretical reputation model, Dan Li's recent new book reveals how the Nanjing government succeeded in establishing a

\footnotetext{
${ }^{18}$ Similarly, while foreign and domestic debts accounted for about $21 \%$ and $3.4 \%$ of total governmental revenue respectively in the Beiyang era, they were about $4 \%$ and 27\% respectively, see Yan 2015, pp. 111-112.
} 
genuine government bond market by taking over and expanding some of the best practices in the Beiyang era (Li 2016, chapter 3). An insightful paper by Brandt and Sargent (1989) invoked the so-called real bills doctrine to explain the close connection between growth in governmental bonds and money supply for this period. They argued that the governmental bond can qualify as a "real bill" as long as there is a firm prospect that sufficient future taxes will be levied to service the debt. With the two major sources being revenue from the Maritime Customs and Salt Taxes, these conditions - certainly before the monetary reform of 1935 - seemed to have been regularly met with both principal and interest payments of various domestic loans having been regularly paid, usually leaving ample balances in the hands of the Sinking Fund Commission (Brandt and Sargent 1989).

The diffusion of Chinese banknotes accelerated with the innovative arrangements where large note-issuing banks such as Bank of China and Bank of Communications offered their banknotes in exchange for cash and government bonds supplied by smaller financial institutions especially Native Banks (Ma 2013). Further, the expansion of branch networks allowed major domestic banks to attract deposits from all regions and recycle them to the areas of greatest demand, contributing to the emergence of an embryonic national market for funds. In the mid-1930s, there were about 160 modern domestic banks in China with over 1300 branches in over 500 localities (Brandt and Sargent 1989, 40; Rawski 1989, pp. 136, 152). The rise of Chinese government bonds and Chinese private banknotes had the significant impact of taking the financial revolution beyond the treaty ports zones where foreign banks usually could not reach. The widespread diffusion of convertible banknotes issued by multiple public and private banks, Chinese or foreign, based on reputation mechanism have led to the triumph of what Denzer-Speck (2009) called a Chinese version of free banking in the Republican period.

The quantitative magnitude of financial revolution can be borne out in Figure 2. It shows that while total species as measured by silver bullion, dollars and copper cash barely registered any increase during 1911-1936, total money supply (M1) which includes species increased at an annual rate of 5\% between 1911-16 and 1931-36. This is only possible because the bank notes and deposit components of M1 surged at a remarkable annual rate of $9.5 \%$ during the same period. As a result, the estimated share of notes and deposits in M1 money supply rose from 22.3-34.6 percent in 1910 to a minimum of 40.4 percent in 1925 and 83.2 percent in 1936 (Rawski 1989, p. 157). As observed in Figure 2, the turning point marked by an uptick in M1 around 1917-18 - after the 1916 banknote suspension incident corresponds closely to the timing of institutional triumph of Chinese modern banks and the subsequent development of Chinese domestic public debt throughout the 1920s and 1930s. Overall Chinese banks - mostly Modern but also including Native Banks - accounted for the lion share of the growth in this period. The deposits held by Chinese Banks relative to foreign 
banks increased from about two times in the 1910s to about four in 1930-35. The same ratio for banknotes held by Chinese over foreign banks increased from 1.5 times to about 3 times for the same period (calculated from Rawski, Table C.15, p. 392) ${ }^{19}$ Remarkably, price level remained stable whereas total money supply nearly tripled between the 1910s and 1930s when annual GDP growth registered no more than two percent during the same period, indicating a heightened degree of monetization and financial deepening (Denzer-Speck 2009, for GDP data, see Rawski, p. 330). They generated economy wide externalities by reducing transaction costs, promoting commercialization and supplying capital for financing industrial, commercial agrarian ventures throughout China. ${ }^{20}$

\section{Insert Figure 2}

In the end, however, politics was more complicated than economics behind China's financial revolution. Both the Settlement and Maritime Customs gained strength at similar junctures by taking advantage of Chinese imperial weakness. As semi-colonial institutions, both organizations were rife with Western racism in their exclusion of Chinese elites and other baggage of Western imperialism. Ironically, it was possibly the mystique of racism or Western supremacy that initially sheltered these institutions from the intrusion of imperial Chinese government. But imperialism cuts both ways as eventually the resentment against imperialism and political disintegration stirred up nationalistic sentiment.

The rise of the new Nationalist government spelled the end of China's short-lived experiment with constitutionalism with renewed attempt to re-establishing a more authoritarian government, initially aided by Soviet military aid and party discipline. The rise of a relatively strong and stable government initially created the favorable conditions that diffusing the fruits of financial revolution in the form of new monetary and financial institutions and instruments unimaginable far beyond what was imaginable during the treaty port framework. More importantly, as pointed out by Dan Li's new book, the nascent Nanjing regime's initial concern for its reputation in the market were also critical to its success in the governmental bonds during 1927-32. But once the regime's hold to power was becoming secure, the reputation effects may be running thin as the government moved to rein in the autonomous power of Western treaty ports, Chinese bankers and China Maritime Customs in the 1930s. By 1935, the Nationalist government took further steps to effectively nationalize

\footnotetext{
${ }^{19}$ These figures are consistent with the so-called "capital power" measure used by Chen Linshen which includes notes and deposits plus capital of the bank. It shows that the share of Modern Banks as measured capital power went from zero in 1894 to $41 \%$ and $78 \%$ respectively 1925 and 1936 relative to the share for Foreign banks which went from $33 \%$ to $37 \%$ and $12 \%$. Overall, the capital of a modern Chinese banking sector multiplied at an annual rate of 10.2\% between 1897 and 1936 (p. 241). For a statistical test on the co-movement of public debts, bank capital and trading volume of stock exchanges, see Yan 2015.

${ }^{20}$ See O'Brien and Palma's recent work showing similar financial revolution emanated from Bank of England in England's post-Glorious Revolution era.
} 
major banks. With the waning of Western imperialism and its associated fiscal-financial nexus but without the simultaneous establishment of an internal form of checks and balances, nationalism in the Chinese context became a two-edge sword. The removal of the one-time external check against potential abuse by the government may well have created conditions for the rise of hyper-inflation in the 1940s, possibly the onset of totalitarianism under the Communist ideologies (Bian 2005, Coble Jr., 1980, chapters seven and eight, Friedman 1992, Brandt and Sargent 1989).

\section{Conclusion}

The rise of constitutionalism and parliamentarianism in the 1910s, which aimed at correcting the shortfalls of the traditional regimes by bringing about constitutional constraint on the rulers, may have instead partly caused the collapse of the state. The state whose power had once been too intrusive to the security of property rights and contract enforcement had then become too weak to protect them. What arose as an imperfect substitute is a set of new institutions - namely the International Settlement and China Maritime Customs - that had grown outside China's imperial regime to offer some limited form of credible commitment to formal property rights and contract enforcement particularly in public debt repayment. These institutions, though fundamentally Western and colonial, had nonetheless inspired the imagination of enlightened Chinese entrepreneurs and officials who took advantage of them to engineer a genuine financial revolution in early $20^{\text {th }}$ century China. In a sharp departure from the traditional political regime where credibility was placed at the mercy or benevolence of a strong and stable state, this particular institutional mechanism actually placed it on a quasi-political structure that had grown autonomous from the center. Interestingly, while constitutionalism may have failed at the national parliament, Chinese bankers and bondholders who enjoyed some form of security of property rights under this institutional mechanism, have for the first time in Chinese history, attempted at numerous occasions to place constraint on the power of the government with regards to fiscal spending (Coble Jr., 49-57 and 115-125). Yet in the end, the political foundation of Chinese bankers began to drift away with the weakening of Western imperialism that had inadvertently provided a certain form of checks and balances on China's authoritarian regime in the absence of constitutional checks. While initially the beneficial effects of political centralization helps diffuse the fruits of financial revolution, it had also steered itself onto a treacherous path of monetary and financial collapse in the face of external and internal warfare that were to follow in the 1940s.

My narrative on the $20^{\text {th }}$ century China offers some revealing insights on the development or lack thereof monetary and financial institution, an issue which have received insufficient attention in the current Great Divergence debate. I show here that the stationary banditry equilibrium along with ruler's unconstrained and arbitrary power in the traditional Chinese 
political regime was insufficient to sustain the rise of a formal and viable market for public debt which in turn may have partly accounted for overall relative underdevelopment of formal financial institution and market in traditional China. ${ }^{21}$ Hence my survey here shows a highly centralized Chinese imperial polity, while not necessarily posing a serious impediment to small-scale informal financial institutions, could be a problem for large and visible formal financial organizations and markets. Hence, my findings contribute to the ongoing debate on state capacity and Great Divergence.

Hence, my article also reveals the dilemma of political and economic reform examined from the longue duree of Chinese history. A perennial theme throughout two millennia of Chinese history is the enduring stability of centralized and unitary imperial rule by punctured by episodic collapse (Ma 2011). But it was often in those brief moments of collapse or gaps between phases of stifling centralization that large ideological shift - made possible by the introduction of new ideas - occurred before being squeezed into another new unitary synthesis of ruling ideology. Often while the reinstallation of unity helped stem short term disintegration and collapse, but the price of stability may well be a new phase of long-term stagnation. In many ways, the period of 1900-1927 represents that temporary moment of suspension from a unitary state, which allowed the massive infusion of institutions and ideologies usually from outside. With the Chinese political regime returning to her centralizing and authoritarian tradition from the 1940s onward, the economic and financial record during this early $20^{\text {th }}$ century Republican experiment offers us a rare glimpse of what an alternative or innovative China could have been if just temporarily freed from the shackles of unity and centralization.

\section{Bibliography (in English):}

Bian, Morris. The Making of the State Enterprise System in Modern China: The Dynamics of Institutional Change (Harvard University Press, 2005)

Boecking, Felix "Unmaking the Chinese Nationalist State: Administrative Reform among Fiscal Collapse,1937-1945" Modern Asian Studies / Volume 45 / Special Issue 02 / March 2011, pp 277 - 301

Brandt, L., Debin Ma and Thomas Rawski. "From Divergence to Convergence: Re-evaluating the History Behind China's Economic Boom" (co-authored with Loren Brandt and Thomas G. Rawski), Journal of Economic Literature 2014, 52(1), 45-123.

Brandt, L., and Thomas Sargent, "Interpreting New Evidences about China and U.S. Silver Purchases," Journal of Monetary Economics 23 (January 1989), pp. 31-51.

\footnotetext{
${ }^{21}$ For an alternative view that relative absence of warfare in China accounting for the lack of development in public debt, see Rosenthal and Wong, 2011, chapters 4 and 5.
} 
Cheng, Linsun, Banking in Modern China, Entrepreneurs, Professional Managers, and the Development of Chinese Banks, 1897-1937. Cambridge: Cambridge University Press. 2003.

Coble Jr., Parks, The Shanghai Capitalists and the Nationalist Government 1927-1937. Cambridge: Harvard University Press. 1980.

Denzer-Speck, D. Freiburg/Br., 2009: "Currency Competition in China Between 1850 and 1950”, Kredit und Kapital, 42. NO.3 327-351.

Dikötter, Frank, 2010, The Age of Openness, China before Mao. Hong Kong University Press.

Friedman, Milton, 'Franklin D. Roosevelt, Silver, and China', in: The Journal of Political Economy, Vol. 100, No. 1, (Feb., 1992), pp. 62-83.

Gao, Pei, Rise from Chaos: the Development of Modern Education in $20^{\text {th }}$ Century China. Phd dissertation, LSE department of economic history. 2015.

Ho, Chun-Yu and Dan Li, 2014. "A mirror of history: China's bond market, 1921-42," Economic History Review, Vol. 67(2), pages 409-434, 05.

Jackson, Isabella, Shaping Modern Shanghai, Colonialism in China's Global City. Cambridge University Press, 2018. .

Jia, Ruixue, "The Legacies of Forced Freedom: China's Treaty Ports", Review of Economics and Statistics, 2014, vol. 96 (4), 596-608.

Kuroda, A., "The Collapse of the Chinese Imperial Monetary System", in Sugihara, K. (eds.), Japan, China, and the Growth of the Asian International Economy, 1850-1949, New York: Oxford University Press, 2005.

Horesh, Niv. Shanghai's bund and beyond: British banks, banknote issuance, and monetary policy in China, 1842-1937. New Haven : Yale University Press, 2009.

Ma, Debin. 2008. "Economic Growth in the Lower Yangzi Region of China in 1911-1937: A Quantitative and Historical Analysis." Journal of Economic History, vol. 68, no. 2: 355-392.

2011. "The Rise of Modern Shanghai in early $20^{\text {th }}$ Century, an Institutional Narrative" chapter 2, in Billy So and Ramon Myers (eds.) The Treaty Port Economy in Modern China, Empirical Studies of Institutional Change and Economic Performance. Berkeley: University of California Press 2011. pp. 33-46.

2012. "Political Institution and Long-run Economic Trajectory: Some Lessons from Two Millennia of Chinese Civilization", chapter 4 in M.Aoki, T.Kuran and G. Roland,eds., Institutions and Comparative Economic Development, Basingstoke: Palgrave Macmillan, 2012, pp.78-98.

, "Chinese Money and Monetary System, 1800-2000, Overview" in Gerard

Caprio (ed.) Handbook of Key Global Financial Markets, Institutions, and Infrastructure, Vol. 1, pp. 57-64. Oxford: Elsevier Inc. (Vol. 1 editors: Charles Calomiris and Larry Neal), 2013.

and Jared Rubin "“The Paradox of Power: Understanding Fiscal Capacity in Qing China, 1644-1911" (co-authored with Jared Rubin) 2017.

https://www.econhistdbm.com/uploads/8/1/9/7/81977286/ma_and_rubin_2017.pdf. 
and Liuyan Zhao "A Silver Transformation, Chinese Monetary Integration in Times of Political Disintegration during 1898-1933" (co-authored with Liuyan Zhao). 2018. LSE

Economic History Working Paper No. 283: http://www.lse.ac.uk/Economic-

History/Assets/Documents/WorkingPapers/Economic-History/2018/WP283.pdf

Ma, Junya, "Traditional Finance and China's Agricultural Trade, 1920-1933" Modern China. Vol. 34, No. 3, July 2008, 344-371.

Mitchner, Kris and Se Yan "Globalization, Trade \& Wages: What Does History tell us about China?" International Economic Review vol. 55(1) (Feb. 2014) 131-168.

Nathan, Andrew Peking Politics, 1918-1923, Fractionalism and the Failure of Constitutionalism University of California Press. 1976.

North, Douglas C., and Weingast, Barry R. "Constitutions and Commitment: The Evolution of Institutions Governing Public Choice in Seventeenth-Century England." Journal of Economic History 49 (Dec. 1989): 803-32.

O'Brien, Patrick and Nuno, Palma "Not an Ordinary Bank but a Great Engine of State: The Bank of England, the Financial Revolution, and the Formation of the British State, 16941821" Working paper, 2014.

Richardson, Philip Economic Change in China, c. 1800-1950. Cambridge University Press 1999.

Rawski, Thomas G. 1989. Economic Growth in Prewar China. Berkeley: University of California Press.

Rosenthal, JL., and Bin Wong, Before and Beyond Divergence: the Politics of Economic Change in China and Europe. Cambridge: Harvard University Press, 2011.

Sheridan, James "The Warlord Era: Politics and Militarism under the Peking Government, 1916-28" in The Cambridge History of China vol. 12, Republican China 1912-1949, Part I. (edited by Denis Twitchett and John Fairbank). Cambridge: Cambridge University Press, 1983.

Shiroyama, Tomoko China during the Great Depression, Market, State, and the World Economy, 1929-1937. Cambridge: Harvard University Press, 2008.

Stasavage, David "What We Can Learn From the Early History of Sovereign Debt" Explorations in Economic History, Volume 59, January 2016, Pages 1-16.

Stephens, Thomas B. 1992. Order and Discipline in China. Seattle and London: University of Washington Press.

Strauss, J. Strong institutions in weak polities: state building in Republican China, 1927-1940. Oxford : Clarendon Press, 1998.

Van den ven, Hans, 2014, Breaking with the Past: The Maritime Customs Service and the GlobalOrigins of Modernity in China (New York, Columbia UP, 2014)

Waldron, Arthur, 1995, From War to Nationalism: China's Turning Point, 1924-1925. Cambridge University Press. 
Wolfgang Keller and Ben Li and Carol Shiue "The Evolution of Domestic Trade Flows when Foreign Trade is Liberalized: Evidence from the Chinese Maritime Customs Service," In Institutions and Comparative Economic Development, Masahiko Aoki, Timur Kuran, and Gérard Roland (eds). New York: Palgrave Macmillan, 2012.

Wright Stanley, China's customs revenue since the Revolution of 1911. Shanghai 1935 3rd ed / revised...with the assistance of J. H. Cubbon, published at the Statistical Department of Inspector General of Customs. Shanghai: Kelly \& Walsh, 1935.

\section{In Chinese:}

Bank of China Economic Research Institute (中国银行总管理处经济研究室) 全国银行年鉴 (Bank Statistical Yearbook ) Publisher: Bank of China Economic Research Institute 1935.

Du, Xuncheng (杜恂诚), 近代中国钱业习惯法一以上海钱业为视角 (The Customary Rules of Chinese Native Banks as viewed from Shanghai Native Banks) Shanghai: Shanghai University of Finance and Economics, 2006.

中国金融通史，第三卷，北洋政府时期 (A General Financial History of Chna, vol. 3: the Beiyang Government), Beijing: China Finance Press, 2002.

Fan, Guo, (樊果) 陌生的守夜人-上海公共租界工部局经济职能研究 (“The Strange "Night watchman" - a Study on the Economic Function of Shanghai Municipal Council） Tianjin: Tianjin Guji Publisher, 2012.

Fei, Chengkang (费成康) 中国租界史 (History of Chinese Concessions) Shanghai Academy of Social Science Publisher, 1991.

Jiang, Liangjin (姜良芹) 南京国民政府内债问题研究( 1927-1937) 一一内债政策及

运作绩效为中心 (The Domestic Debt in Nanjing Government in 1927-1937) Nanjing University Press, 2003.

Li, Dan (李丹) 历史“大数据”，民国证奇市场之量化研究 (“Big Data” in History, The Development of Security and Bond Markets in Republican China). Peking University Press, 2016.

Liu, Xiaoquan (刘晓泉) 北洋政府内国公债发行研究 (A Study on the Domestic Public Debt by Beiyang Government). A Phd thesis submitted to Hunan Normal University, 2008.

Ma, Changwei, Huiyuan Yao (马长伟，姚会元) “近代中国政府三次债务整理案的比较研 究” (A Comparative Study on three cases of public debt restructuring in Modern China) Journal of Jiangxi University of Finance and Economics, No. 2, 2014; pp.87-96.

Yan, Hongzhong（燕红忠）2012. 中国的货币金融体系（1600-1949） Monetary and Financial Systems of Modern China from 1600-1949: A Study on Economic Performance and Modernization ). Beijing: China People's University Press. 
2015, 近代中国的政府债务与金融发展 (Governmental Debts and Financial Development in Modern China). 财经研究 (Journal of Finance and Economics), Vol. 41, No. 9, Sept. 2015. Pp.108-120.

Yang Xiaoyan (杨晓燕）上海公共租界工部局的市政管理（1854-1943) (Urban Management in Shanghai Municipal Council (1854-1943). Phd Dissertation, Shanghai University of Finance and Economics, 2014.

\section{In Japanese:}

Minami, R. and Makino, F. (南亮進、牧野文夫) 2014, アジア長期経済統計（3）中国。 Asian Historical Statistics: China. Tokyo: Toyo Keiza Shinbumsha.

Okamoto, Takashi,（岡本隆司）1999, 近代中國與海關 ( China and the Maritime Customs System in Modern Times) Nagoya: Nagoya University Press. 
Figure 1. Bond Prices for the 1914 Bond in 1915-1925

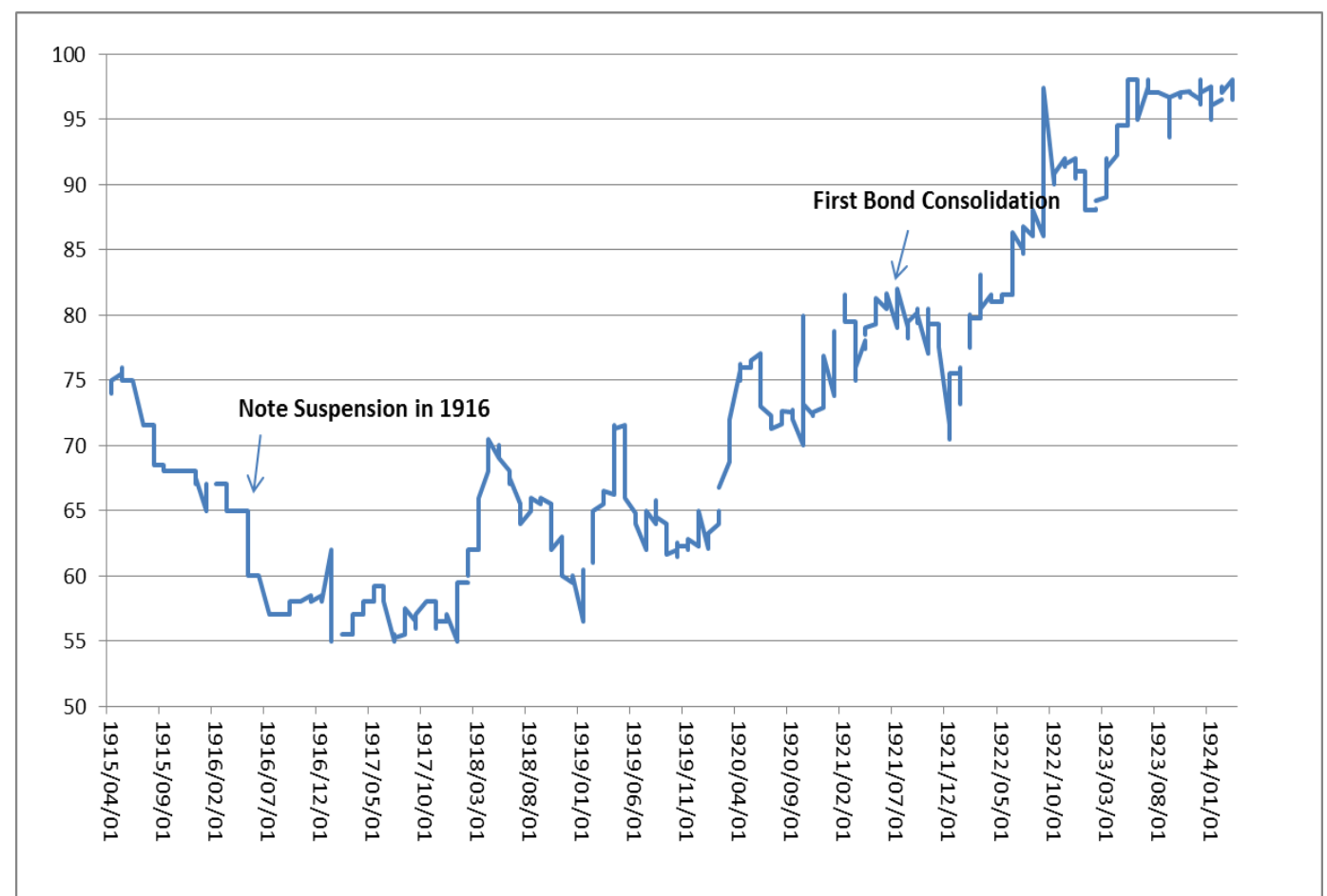

Notes: The 1914 bond had a $6 \%$ interest with a 12 year maturity. It was paid off completely in 1925 . The bond payment was initially securitized on revenue from the railroads, later on Native Customs revenue and Maritime Customs revenue. See Liu 2008, p. 214.

Source: Shanghai Shenbo Daily, 1915-1924. The price data were mostly quoted for Friday (end of the day). When the price data were not available on Fridays (Friday was a holiday, or account day 交割日), we quote the price of the nearest day, first from Saturday (the last trading in a week) and then, Thursday and Wednesday. I want to thank Professor Li Dan for sharing her data. 
Figure 2 Species and Money Supply in China in 1911-1936 (in Million Yuan)

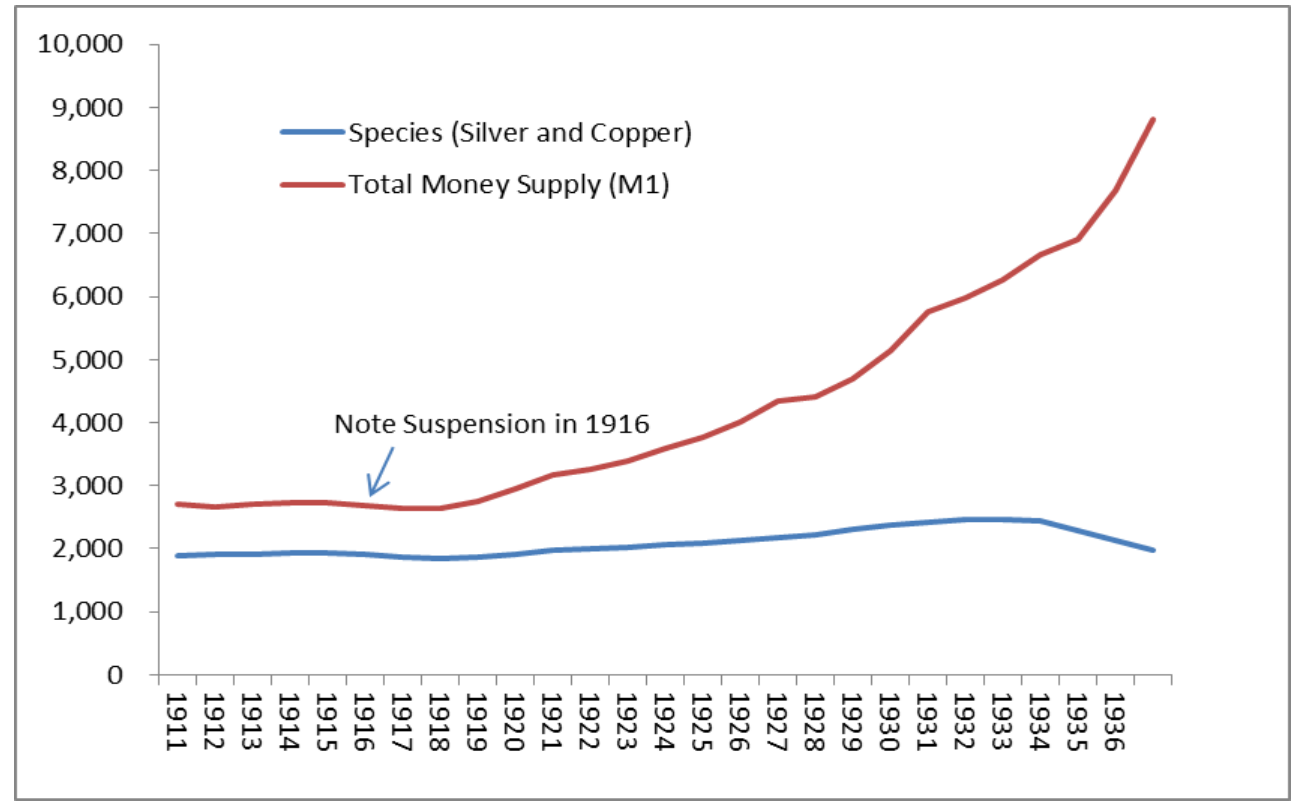

Notes: M1 is equal to species plus bank notes and deposits. Bank notes, Silver, Copper currency from Minami and Makino 2014, Table. 5.2.1. Bank deposits data from Rawski 1989, Table c.16, p. 394. 